\title{
Megakaryocyte Growth and Development Factor Is a Potent Growth Factor for Primitive Hematopoietic Progenitors in the Human Fetus
}

\author{
MARCUS O. MUENCH AND ALICIA BÁRCENA \\ Department of Laboratory Medicine, University of California, San Francisco, San Francisco, CA 94143, \\ U.S.A.
}

\begin{abstract}
Megakaryocyte growth and development factor (MGDF), or thrombopoietin, has received considerable attention as a therapeutic agent for treating thrombocytopenia or for its use in the ex vivo culture of hematopoietic stem cells. MGDF is known to support the growth of a broad spectrum of hematopoietic precursors obtained from adult or neonatal tissues, but its effects on the growth of fetal progenitors and stem cells has not been studied. Human $\mathrm{CD} 38^{+} \mathrm{CD} 34^{2+}$ progenitors and CD $38^{-}$CD $34^{2+}$ cells, a population that contains stem cells, were isolated from midgestation liver and grown under defined conditions with MGDF and various cytokines known to support the growth of primitive hematopoietic precursors. In clonal assays of colony-forming cells (CFCs), MGDF supported the growth of $15-25 \%$ of candidate stem cells when combined with granulocyte colony-stimulating factor, granulocyte-macrophage colony-stimulating factor (GM-CSF), flk2/flt3 ligand, or stem cell factor. MGDF was observed to strongly support the early stages of hematopoiesis and expansion of high proliferative potential CFCs. More mature progenitors were expanded nearly 78 -fold in 1 wk of culture with
\end{abstract}

\section{ABSTRACT}

$\mathrm{MGDF}+\mathrm{SCF}+\mathrm{GM}-\mathrm{CSF}$. MGDF alone was also found to support the short-term $(2 \mathrm{~d})$ survival of $\mathrm{CD} 38^{-} \mathrm{CD} 34^{2+}$ high proliferative potential CFCs. The effects of MGDF were more modest on $\mathrm{CD} 38^{+} \mathrm{CD} 34^{2+}$ progenitors with only additive increases in colony formation being observed. These findings suggest that MGDF administration in fetuses and neonates may strongly affect the growth and mobilization of primitive hematopoietic progenitors and that MGDF may find use in the ex vivo growth and expansion of fetal stem cells. (Pediatr Res 55: 1050-1056, 2004)
CFC, colony-forming cell
Abbreviations
FL, flk-2/flt3 ligand
G-CSF, granulocyte colony-stimulating factor
GM-CSF, granulocyte-macrophage colony-stimulating factor
HPP, high proliferative potential
LPP, low proliferative potential
MGDF, megakaryocyte growth and development factor
SCF, stem cell factor

Megakaryocyte growth and development factor (MGDF) is the major regulator of megakaryocyte development and platelet production (reviewed in Refs. $(1,2)$ ). MGDF has been isolated from the sera of a number of mammalian species, in which its levels have been found to correlate inversely with peripheral blood platelet counts. Furthermore, the administration of MGDF has shown this cytokine to be a potent stimulator of thrombopoiesis, hence its other name thrombopoietin. The thrombopoietic effects of MGDF are the result of its ability to promote the growth and maturation of megakaryocytes. MGDF

Received October 3, 2003; accepted January 15, 2004.

Correspondence: Marcus O. Muench, Ph.D. University of California at San Francisco; 513 Parnassus Ave., Room HSW-901B; San Francisco, CA 94143-0793, U.S.A.; e-mail: muench@itsa.ucsf.edu

This work was supported in part by National Institutes of Health Grant DK59301 and an Individual Investigator Research grant from the University of California at San Francisco Academic Senate (M.O.M.).

DOI: 10.1203/01.pdr.0000127020.00090.51 can stimulate, both in vitro and in vivo, an increase in megakaryocyte production and megakaryocyte ploidy. Administration of MGDF as a treatment for neonatal thrombocytopenia is being studied (3-5).

MGDF also supports the growth of multipotent hematopoietic progenitors and stem cells. The administration of MGDF to mice after cytoablative injury has resulted in an accelerated recovery of myeloid and multilineage progenitors in addition to an increase in megakaryocytic progenitors (6). Moreover, mice deficient in MGDF or its receptor, c-mpl, have reduced numbers of committed and multipotent progenitors $(7,8)$, indicating a role for MGDF in the in vivo regulation of the early stages of hematopoiesis. These findings are further supported by observations of synergism between MGDF and other cytokines in increasing the growth of purified stem cells isolated from murine adult bone marrow (9, 10). In humans, c-mpl mRNA expression was detected among adult bone marrow cells with the phenotypic characteristics $\left(\mathrm{CD} 38^{-} \mathrm{CD} 34^{2+}\right)$ associated with stem cells (11). MGDF alone 
was shown to stimulate the production of megakaryocytes and neutrophils from $\mathrm{CD} 38^{-} \mathrm{CD} 34^{2+}$ cells grown under serumdeprived conditions (12). MGDF was also observed to synergize with a number of other early-acting growth factors to promote the growth of human primitive progenitors $(13,14)$. MGDF has further found application in protocols used to expand hematopoietic progenitors ex vivo owing to the broad range of hematopoiesis supported by MGDF $(2,15)$.

The primary site of MGDF production throughout human ontogeny is the liver (16-18). MGDF mRNA has also been detected in the fetal and adult bone marrow as well as in organs such as kidney and spleen. The levels of MGDF in plasma are higher in the fetus and neonate than in the adult $(17,19,20)$. The presence of MGDF in fetal hematopoietic tissues, such as the liver and bone marrow, indicates that this cytokine is a likely physiologic regulator of fetal hematopoiesis. Megakaryocyte progenitors isolated from human fetal tissues have been shown to respond to MGDF in vitro (21-24). MGDF has also been found to support the growth, when combined with either IL-3 or stem cell factor (SCF), of primitive progenitors isolated from murine fetal livers (25). The response of fetal hematopoietic progenitors to cytokines has been found to differ from that of adult and even neonatal progenitors. Fetal progenitors generate a larger number of progeny and can differ in their response to cytokines compared with their adult counterparts (26-31). The role of MGDF in the regulation of the early stages of fetal hematopoiesis in the human is unclear. The goal of this study was to determine whether MGDF can support the growth of primitive hematopoietic progenitors isolated from human fetal liver because MGDF may have application in the realm of fetal and neonatal therapies.

\section{METHODS}

Isolation of human fetal liver progenitors. Human fetal livers were obtained from elective abortions at the University of California San Francisco and from Advanced Bioscience Resources (Alameda, CA, U.S.A.). Fetal tissue was used with the approval of the Committee for Human Research at University of California San Francisco and with the consent of the women undergoing the abortion. The gestational age of the tissues was estimated on the basis of the foot-length of the fetus and ranged from 16 to $24 \mathrm{wk}$. A detailed protocol describing the isolation of lineage-depleted $\left(\mathrm{CD}^{-}, \mathrm{CD}^{-} 4^{-}, \mathrm{CD}^{-} 9^{-}\right.$, $\mathrm{CD} 20^{-}$, and $\left.\mathrm{CD} 56^{-}\right) \mathrm{CD} 38^{+} \mathrm{CD} 34^{2+}$ and $\mathrm{CD} 38^{-} \mathrm{CD} 34^{2+}$ fetal liver cells used in this study has been published and is freely available on the internet (32).

Cytokines. Recombinant human MGDF, granulocyte colony-stimulating factor (G-CSF), granulocyte-macrophage CSF (GM-CSF), flk-2/flt3 ligand (FL), and SCF were provided by Amgen (Thousand Oaks, CA, U.S.A.). MGDF, G-CSF, and GM-CSF were used at $20 \mathrm{ng} / \mathrm{mL}$ unless otherwise stated. FL and SCF were used at $100 \mathrm{ng} / \mathrm{mL}$ and $50 \mathrm{ng} / \mathrm{mL}$, respectively. These cytokine concentrations support the growth of a maximal number of colony-forming cells (CFCs) in assays performed under serum-deprived culture conditions.

CFC assays. Myeloid CFC numbers were determined in triplicate double-layered clonal cultures as previously described
$(29,30)$. These cultures consisted of a total volume of $3 \mathrm{~mL}$ of serum-deprived culture medium (33) consisting of IMDM (Life Technologies, Grand Island, NY, U.S.A.) supplemented with 7.5 $\times 10^{-5} \mathrm{M} \alpha$-thioglycerol (Sigma Chemical Co., St. Louis, MO, U.S.A.), $50 \mu \mathrm{g} / \mathrm{mL}$ gentamicin, $2 \%$ fraction- $\mathrm{V}$ ethanol-extracted BSA (Roche Applied Science, Indianapolis, IN, U.S.A.), 200 $\mu \mathrm{g} / \mathrm{mL}$ human iron-saturated transferrin (Serologicals Proteins, Kankakee, IL, U.S.A.), $10 \mu \mathrm{g} / \mathrm{mL}$ rh-insulin (Roche Applied Science), and $20 \mu \mathrm{g}$ protein $/ \mathrm{mL}$ human LDL (Sigma Chemical Co.). SeaPlaque agarose (FMC, Rockland, ME, U.S.A.) was used as the semisolid matrix for these cultures at a concentration of $0.5 \%$ in the lower layer and $0.36 \%$ in the upper layer. After $3 \mathrm{wk}$ of growth at $37^{\circ} \mathrm{C}$ in a fully humidified atmosphere, three classes of CFC were scored on the basis of the size of the hematopoietic colonies generated: high-proliferative potential (HPP) CFCs, lowproliferative potential (LPP) CFCs, and clusters. HPP-CFCs were defined by colonies that contained approximately $1 \times 10^{4}$ to $1 \times$ $10^{6}$ cells $(29,34)$. LPP-CFCs were defined by colonies smaller than HPP-CFCs but $>50$ cells/colony. Clusters were defined as colonies that contained $10-50$ cells. The sum of all three CFC types is referred to as total CFCs. Multipotent CFCs that are capable of generating erythroid and myeloid cells were detected in methyl cellulose-based cultures as previously described in detail (35).

Delayed-cytokine-addition experiments were used to study the effects of MGDF on the survival of $\mathrm{CD} 38^{-} \mathrm{CD} 34^{2+} \mathrm{Lin}^{-}$ fetal liver progenitors as previously reported $(30,31)$. Briefly, clonal cultures were established using the serum-deprived culture medium with or without MGDF. A second addition of cytokines was performed at 1, 2, 3, 4, or $7 \mathrm{~d}$ after the initiation of culture, resulting in a final growth stimulus of $\mathrm{MGDF}+\mathrm{SCF}+\mathrm{GM}-\mathrm{CSF}$. Cytokines added after the initiation of the cultures were added in a volume of $30 \mu \mathrm{L}$ to the top of the semisolid cultures. Cultures stimulated with $\mathrm{MGDF}+\mathrm{SCF}+\mathrm{GM}-\mathrm{CSF}$ from the beginning of culture were used to determine the number of CFCs seeded. SCF and GM-CSF were used in these cultures because these cytokines stimulate a broad range of myeloid progenitors and support the growth of a high frequency of HPP-CFCs (30).

Delta assay. The effects of MGDF, alone or in combination with other cytokines, on the growth of primitive progenitors during liquid culture were determined using the $\Delta$ assay (30). Duplicate or quadruplicate liquid cultures were initiated with $900 \mathrm{CD} 38^{-} \mathrm{CD} 34^{2+}$ fetal liver cells in $1 \mathrm{~mL}$ of serum-deprived medium supplemented with or without cytokines. Primary $\mathrm{CFCs}$ were determined in parallel from triplicate cultures of $300 \mathrm{CD}^{-} 8^{-} \mathrm{CD} 34^{2+} \mathrm{Lin}^{-}$fetal liver cells grown in serumdeprived medium supplemented with SCF + GM-CSF. After $7 \mathrm{~d}$ of liquid culture, cells were harvested and washed, and secondary clonal cultures were established using identical culture conditions as used for the primary assays. The secondary CFC assays were initiated with dilutions of the cultured cells. The dilutions were determined on the basis of the degree of cellular expansion observed with the different cytokine combinations and were made to seed $\sim 750$ cells/culture when a sufficient degree of expansion had occurred. The change $(\Delta)$ in the number of cells and CFCs between the onset of liquid 
culture and after $7 \mathrm{~d}$ of growth was determined by dividing the primary by the secondary values.

Data presentation and statistical analysis. The data are presented as the mean \pm 1 SEM of the results obtained from multiple experiments. The results of replicate CFC measurements for each individual experiment were averaged before use in calculating the mean of multiple experiments. The unpaired $t$ test was used to determine the probability of differences between culture conditions from individual experiments. Differences were considered significant at $p \leq 0.05$.

\section{RESULTS}

MGDF supports colony formation by candidate stem cells. For establishing that MGDF supports the growth of primitive progenitors from human fetal liver, purified progenitors were grown in clonal assays under serum-deprived conditions (Fig. 1). Two precursor populations were studied, $\mathrm{CD} 38^{-} \mathrm{CD} 34^{2+} \mathrm{Lin}^{-}$ and $\mathrm{CD} 38^{+} \mathrm{CD} 34^{2+} \mathrm{Lin}^{-}$cells. The former population, lacking CD38 expression, contains stem cells, although it may also contain committed progenitors. The latter population, which expresses $\mathrm{CD} 38$, is composed of immature progenitors that do not have stem cell capacity $(29,32,35)$.

MGDF alone supported colony formation by a small number of $\mathrm{CD} 38^{-} \mathrm{CD} 34^{2+} \mathrm{Lin}^{-}$candidate stem cells (Fig. 1). An average of $6 \pm 2$ total $\mathrm{CFCs} / 1.0 \times 10^{3} \mathrm{CD} 38^{-} \mathrm{CD} 34^{2+} \mathrm{Lin}^{-}$cells were detected in cultures with MGDF, whereas no colony formation was detected in cultures in the absence of any added growth factors ( $p \leq 0.014, n=3$ ). The effects of MGDF were compared with those of G-CSF, GM-CSF, FL, and SCF, growth factors that have been shown previously to support the growth of $\mathrm{CD} 38^{-} \mathrm{CD} 34^{2+} \mathrm{Lin}^{-}$fetal liver cells $(30,31)$. MGDF supported the growth of a greater number of total CFCs in two of three experiments compared with G-CSF and GM-
CSF $(p<0.05)$. The numbers of CFCs supported by MGDF and FL were similar, whereas SCF supported the growth of more total CFCs than observed with MGDF, G-CSF, GM-CSF, and FL ( $p<0.044, n=3)$. The level of proliferation supported by any of these cytokines individually was very low, with most colonies containing $<50$ cells.

Synergism in supporting colony formation was observed between MGDF and G-CSF, GM-CSF, FL, or SCF (Fig. 1). Combining MGDF with a second cytokine increased colony formation from 3.7-fold with MGDF+FL to 5.5-fold with MGDF+SCF. Approximately one quarter of all $\mathrm{CD} 38^{-} \mathrm{CD} 34^{2+} \mathrm{Lin}^{-}$cells placed in culture formed colonies in the presence of MGDF+SCF. In addition to recruiting more progenitors to form colonies, combining MGDF with a second cytokine resulted in a modest increase in colony size. This was apparent by the presence of colonies derived from LPP-CFCs in the cultures supported by two cytokines, although no HPPCFCs were detected under any of the conditions tested. These findings indicate that MGDF directly supports the growth of $\mathrm{CD} 38^{-} \mathrm{CD} 34^{2+} \mathrm{Lin}^{-}$cells originating from fetal liver.

\section{MGDF supports the survival of HPP-CFCs.} $\mathrm{CD} 38^{-} \mathrm{CD} 34^{2+} \mathrm{Lin}^{-}$fetal liver cells are enriched for progenitors with an extensive in vitro proliferative capacity, consistent with the presence of stem cells among this population of cells (29). Because none of these HPP-CFCs were detected in cultures of $\mathrm{CD} 38^{-} \mathrm{CD} 34^{2+} \mathrm{Lin}^{-}$cells grown under any of the culture conditions shown in Fig. 1, the possibility that MGDF affected the growth only of a more mature subpopulation of these cells existed. This possibility was disproved in experiments in which clonal cultures of $\mathrm{CD} 38^{-} \mathrm{CD} 34^{2+} \mathrm{Lin}^{-}$cells were initiated with or without MGDF, followed by a second addition of growth factors that supported the growth of HPPCFCs. The combination SCF+GM-CSF was used in these

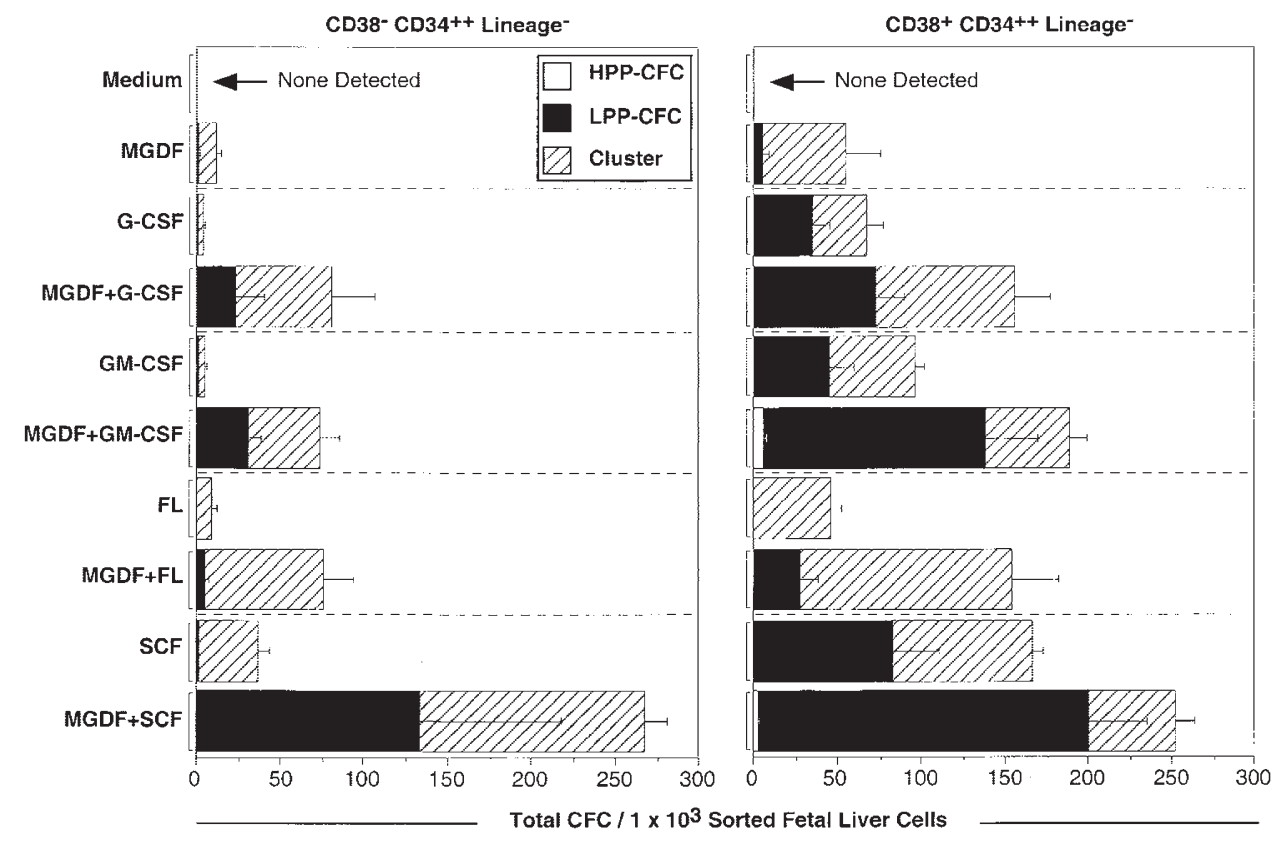

Figure 1. Effects of MGDF on colony formation by $\mathrm{CD} 38^{-} \mathrm{CD} 34^{2+} \mathrm{Lin}^{-}$and $\mathrm{CD} 38^{+} \mathrm{CD} 34^{2+} \mathrm{Lin}^{-}$cells. The mean \pm SEM of $\mathrm{CFCs}-\mathrm{segregated}$ on the basis of size into clusters, LPP-CFCs, and HPP-CFCs - are indicated per $1 \times 10^{3}$ sorted fetal liver cells. Three experiments were performed using CD38 ${ }^{-} \mathrm{CD}^{2} 4^{2+} \mathrm{Lin}^{-}$ cells, and four experiments were performed using $\mathrm{CD} 38^{+} \mathrm{CD} 34^{2+} \mathrm{Lin}^{-}$cells. 
experiments to support the growth of HPP-CFCs (30). As shown in Fig. $2 A$, the inclusion of MGDF in cultures stimulated by SCF + GM-CSF did not significantly change the number of HPP-CFCs or LPP-CFCs detected ( $p>0.22, n=3$ ).

Delaying the addition of growth factors by at least $2 \mathrm{~d}$ resulted in a significant decline in $\mathrm{CFC}$ viability in cultures initiated in the absence of cytokines (Fig. 2B). In contrast, both HPP-CFCs and LPP-CFCs were better maintained by the presence of MGDF at the initiation of culture. CFCs did show a time-dependent decrease in cultures initiated with MGDF. The decreases were modest and usually insignificant during the first $3 \mathrm{~d}$ of culture. By the fourth day of culture, the numbers of CFCs detected in either cultures initiated with MGDF or those begun in the absence of cytokine had declined significantly. However, increased survival of CFCs cultured in the presence of MGDF was observed even when the addition of

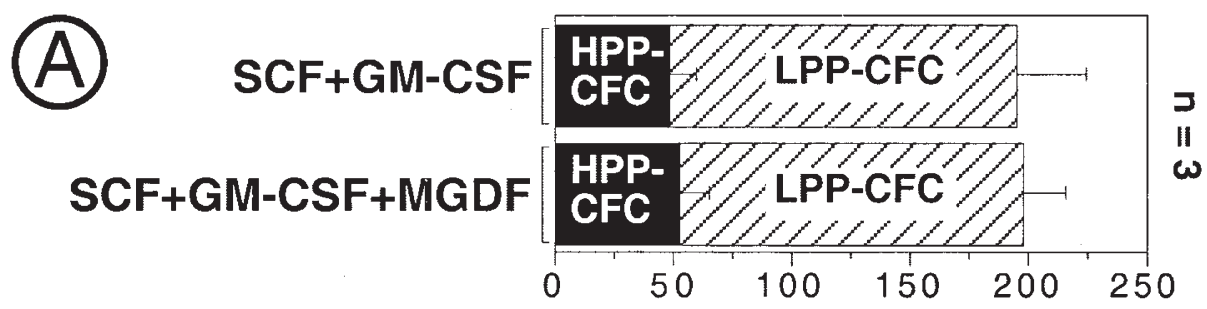

Total CFC / 1 × $10^{3}$ CD38-CD34++Lin- Cells

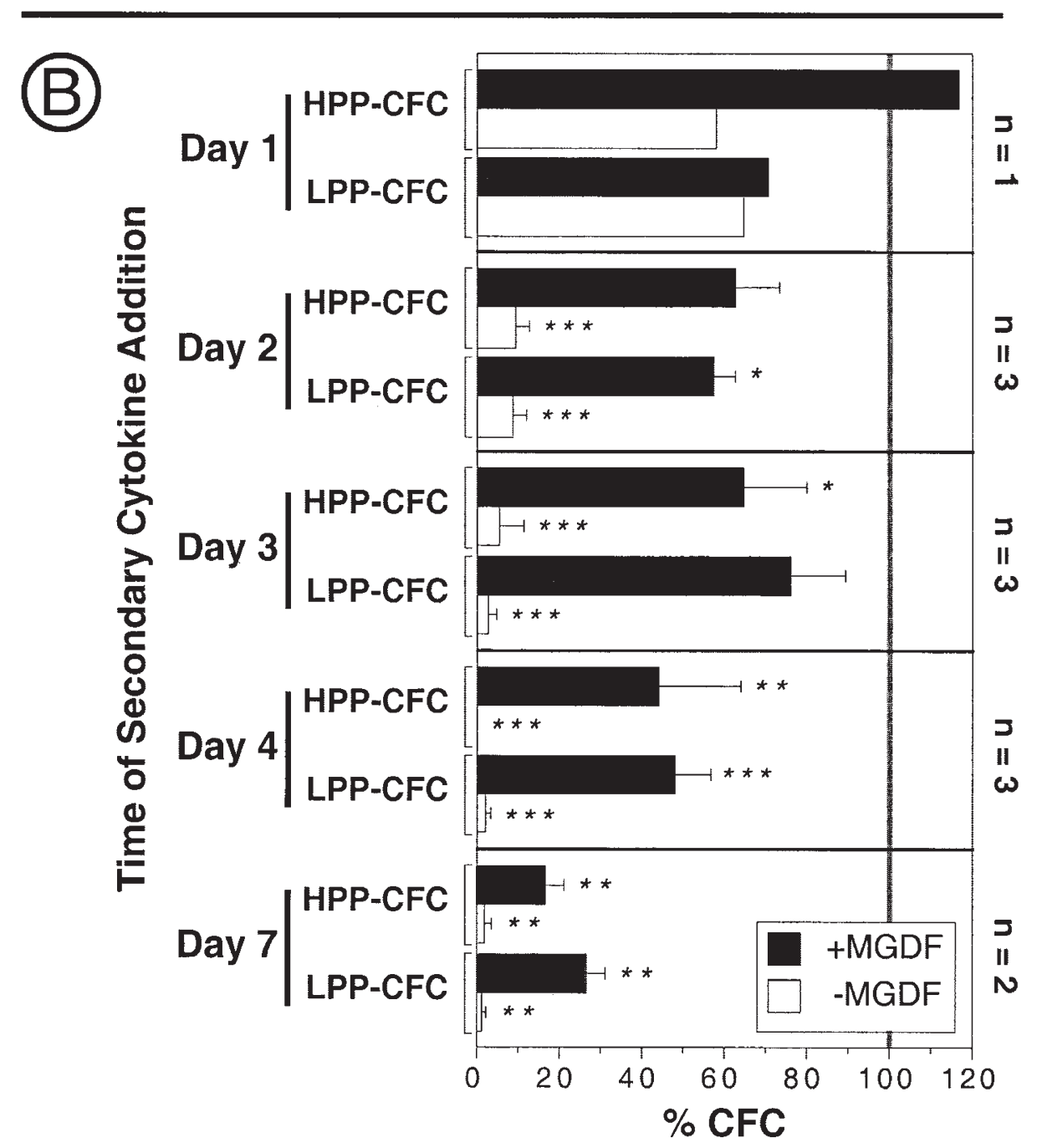

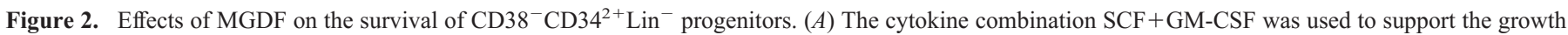

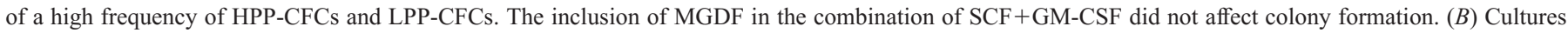

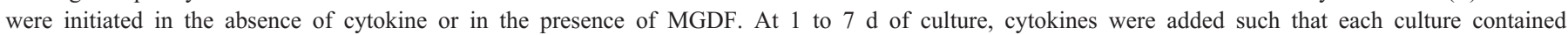

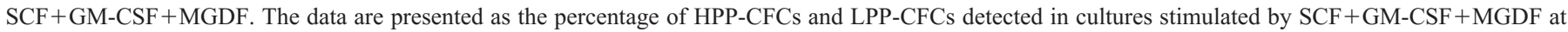

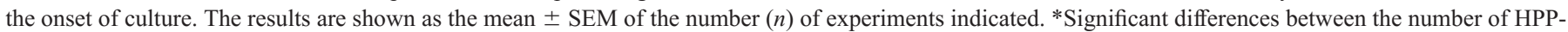

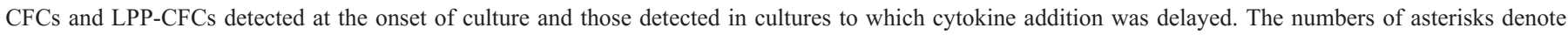
the number of experiments in which the differences were found to be significant. 
$\mathrm{SCF}+\mathrm{GM}-\mathrm{CSF}$ was delayed until $7 \mathrm{~d}$ of culture. These data demonstrate that MGDF directly affects at least a subset of $\mathrm{CD} 38^{-} \mathrm{CD} 34^{2+} \mathrm{Lin}^{-}$progenitors in the absence of any other growth factors and that some of the progenitors responsive to MGDF have the potential for a high degree of proliferation.

MGDF supports colony formation by immature progenitors. MGDF also supported significant levels of colony formation by $\mathrm{CD} 38^{+} \mathrm{CD} 34^{2+} \operatorname{Lin}^{-}(p \leq 0.013, n=4$ experiments; Fig. 1$)$. In a dose-response experiment, the number of colonies supported by MGDF reached a peak at $20 \mathrm{ng} / \mathrm{mL}$, but significant growth was observed even at $0.5 \mathrm{ng} / \mathrm{mL}$ (data not shown), indicating that the $20 \mathrm{ng} / \mathrm{mL}$ of MGDF used throughout this study was optimal. The numbers of total CFCs supported by MGDF was comparable to that supported by either G-CSF or FL but was somewhat less than that supported by GM-CSF ( $p \leq 0.016, n=3$ of 4 experiments). SCF consistently supported more CFC growth than MGDF $(p<$ $0.001, n=4$ experiments).

Combining MGDF with any of the other cytokines tested resulted in increased growth of $\mathrm{CD} 38^{+} \mathrm{CD} 34^{2+} \mathrm{Lin}^{-}$progenitors, similar to what was observed with the cultures of candidate stem cells. However, the degree of synergism observed with the cytokine combinations was low, ranging from 1.1- to 1.5 -fold, compared with the super-additive effects on the more primitive $\mathrm{CD} 38^{-} \mathrm{CD} 34^{2+} \mathrm{Lin}^{-}$precursors. The numbers of total CFCs detected in cultures stimulated with two cytokines was significantly higher than the numbers detected with the individual cytokines in all but one sample ( $p \leq 0.05, n=4)$.

Synergism between MGDF and other growth factors in promoting the expansion of progenitors. The effects of MGDF on the growth of $\mathrm{CD} 38^{-} \mathrm{CD} 34^{2+} \mathrm{Lin}^{-}$cells were further assessed using the $\Delta$ assay (Fig. 3). In seven experiments, the number of HPP-CFCs recovered from MGDF-stimulated cultures was $1.3 \pm$ 0.4-fold higher than input, which was comparable to the recovery of HPP-CFCs from SCF-stimulated cultures $(p>0.05)$. In the majority of experiments, the maintenance of HPP-CFCs by
MGDF was significantly greater than that supported by G-CSF, GM-CSF, or FL $(p \leq 0.05)$. The results were similar for LPPCFCs. The pattern observed using the $\Delta$ assay mirrored the pattern of colony growth from $\mathrm{CD} 38^{-} \mathrm{CD} 34^{2+} \mathrm{Lin}^{-}$progenitors supported by individual growth factors (Fig. 1). The $\Delta$ assay data further indicate that MGDF does promote the growth of a subset of early progenitors with a high level of proliferative potential even though HPP-CFCs were not detected in clonal cultures supported by MGDF alone.

Notable expansion of CFCs required combinations of cytokines (Fig. 3). The synergism between MGDF and SCF resulted in the greatest average expansion of HPP-CFCs $(\Delta 10.7$ $\pm 2.9)$ and LPP-CFCs $(\Delta 26.8 \pm 6.9)$ observed with any of the cytokine pairs that contained MGDF $(n=7)$. However, the expansion of HPP-CFCs supported by MGDF+SCF was less than half the $22.5 \pm 8.1$-fold expansion stimulated by $\mathrm{SCF}+\mathrm{GM}-\mathrm{CSF}$, although the differences between these two groups were significant in only three of seven experiments. Thus, the combination MGDF $+\mathrm{SCF}$ likely promotes the growth of the same population of HPP-CFCs as SCF+GMCSF, because combining MGDF with SCF + GM-CSF promoted a similar expansion of HPP-CFCs as seen with $\mathrm{SCF}+\mathrm{GM}-\mathrm{CSF}$. The combination $\mathrm{MGDF}+\mathrm{SCF}+\mathrm{GM}-\mathrm{CSF}$ did provide the greatest expansion of LPP-CFCs $(\Delta 77.8 \pm$ 15.9), which was greater than the combined effects of $\mathrm{MGDF}+\mathrm{SCF}$ and SCF + GM-CSF $(p<0.05$ in at least six of seven experiments). These results indicate that the triadic cytokine combination supports the growth of a broader spectrum of progenitors that develop during the 1-wk culture period than do $\mathrm{MGDF}+\mathrm{SCF}$ or $\mathrm{SCF}+\mathrm{GM}-\mathrm{CSF}$.

\section{DISCUSSION}

Hematopoiesis is regulated by a variety of growth factors that act at different stages of hematopoiesis to support or inhibit
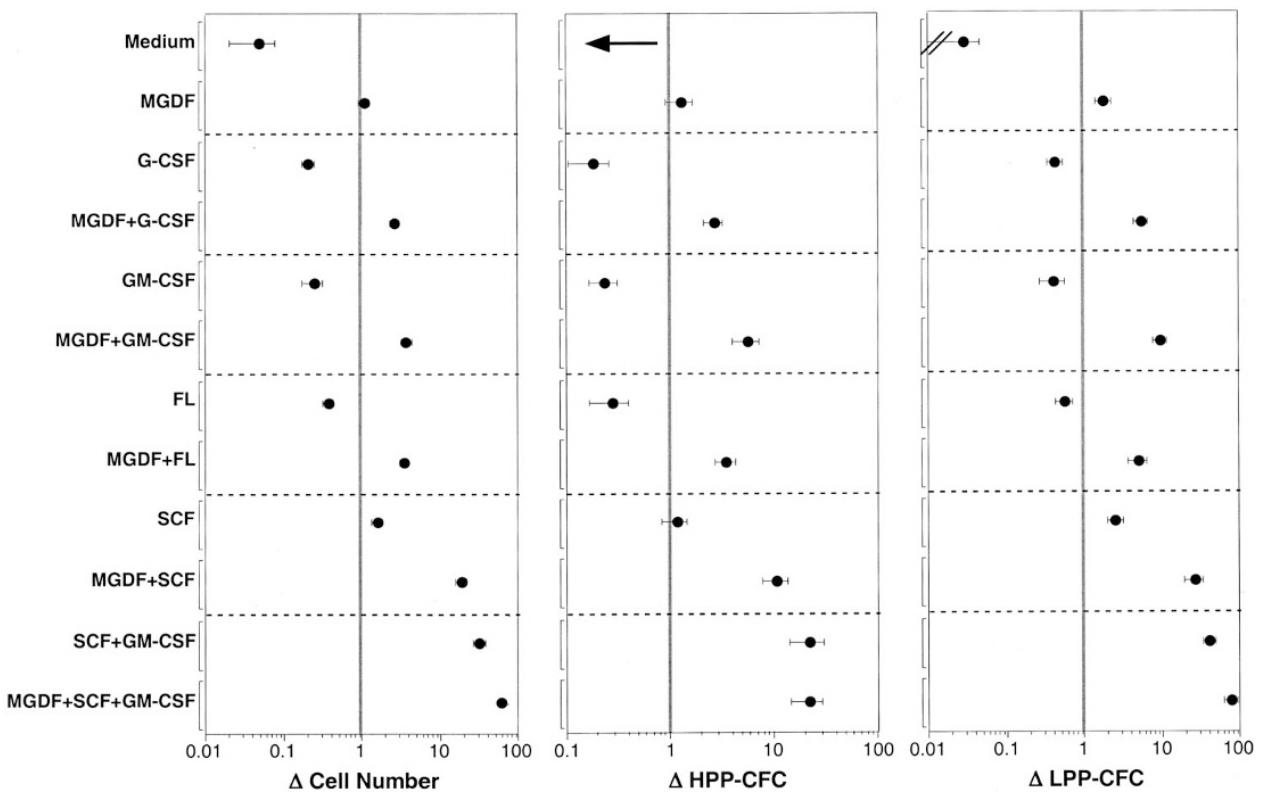

Figure 3. Effects of MGDF on the expansion of myeloid progenitors from CD $38^{-} \mathrm{CD} 34^{2+} \mathrm{Lin}^{-}$cells. The data are presented as the mean change $(\Delta)$ in cell, HPP-CFC, and LPP-CFC numbers \pm SEM ( $n=7$ to 8 experiments). $\Delta$ HPP-CFC could not be calculated for cells grown in serum-deprived medium alone (arrow), because no secondary HPP-CFCs were detected. Note that the $\Delta$ values are shown on a logarithmic scale and that vertical lines mark the input values. 
the production of specific lineages of blood cells. The production of different cell lineages is in many cases regulated primarily by a single growth factor, such as the control of erythropoiesis by erythropoietin or support of megakaryocytopoiesis and thrombopoiesis by MGDF. In contrast, the early events in hematopoiesis are susceptible to regulation by a large number of cytokines, many of which are also important regulators of the final stages of hematopoietic development for specific cell lineages. MGDF is among these pleiotropic cytokines in that it has a broad spectrum of activity on hematopoiesis $(1,2)$. Herein, we demonstrate that MGDF is an important regulator of the growth of early hematopoietic progenitors and, likely, stem cells in the human fetus.

Several lines of evidence indicate that MGDF is capable of supporting the growth and survival of fetal primitive progenitors and/or stem cells. MGDF was found to support the growth of CFCs found among CD $38^{-} \mathrm{CD} 34^{2+} \mathrm{Lin}^{-}$cells. These candidate stem cells are known to require the presence of at least two cytokines for more than just a small number of CFCs to grow $(30,31)$. Indeed, synergism was observed between MGDF and each of the other early-acting cytokines tested. Synergism in stimulating the growth of $\mathrm{CD} 38^{-} \mathrm{CD} 34^{2+} \mathrm{Lin}^{-}$ cells was also observed in the $\Delta$ assay, which demonstrated that MGDF could support the survival and expansion of CFCs. The size of colonies generated in the presence of MGDF and the degree of progenitor expansion supported by combinations of cytokines including MGDF was lower than with combinations such as $\mathrm{SCF}+\mathrm{GM}-\mathrm{CSF}$. This observation is attributed to the limited range of hematopoietic activity that MGDF has on the late stages of hematopoiesis and the relatively few numbers of megakaryocytes generated as a result of endomitosis. Although MGDF did not produce large colonies when paired with other early-acting cytokines, the results from delayedcytokine-addition experiments and from the $\Delta$ assay demonstrated that MGDF did support the growth of HPP-CFCs. Indeed, the ability of MGDF alone to support the short-term survival of HPP-CFCs observed in the delayed-cytokineaddition experiments was similar to that previously observed of SCF, FL, GM-CSF, G-CSF, and IL-3 on fetal $\mathrm{CD} 38^{-} \mathrm{CD} 34^{2+} \mathrm{Lin}^{-}$cells $(30,31)$. Because MGDF did not enhance the growth of $\mathrm{CD} 38^{-} \mathrm{CD} 34^{2+} \mathrm{Lin}^{-}$cells observed with SCF+GM-CSF, it can be deduced that MGDF supports the growth of the same progenitors as affected by SCF and GM-CSF. Together these findings indicate that MGDF is active in supporting the growth of $\mathrm{CD} 38^{-} \mathrm{CD} 34^{2+} \mathrm{Lin}^{-}$cells and can be included with SCF, FL, GM-CSF, G-CSF, and IL-3 in the category of fetal stem cell growth factors $(30,31)$.

As with most tissues in the fetus, hematopoietic tissues undergo a level of growth unparalleled later in life to accommodate the need both to expand the size of the hematopoietic tissues and to keep pace with the increasing volume of peripheral blood. A number of studies have indicated differences in how fetal and postnatal progenitors respond to growth factors and growth inhibitors $(27-30,36)$. Fetal stem cells are also known to have a greater proliferative capacity both in vitro and in vivo $(26,37)$. The findings in this study reveal further differences in how fetal and adult hematopoietic progenitors respond to cytokines. Although primitive progenitors/stem cells from both fetal and adult sources respond to MGDF, the response of fetal tissues seems to be greater. In a study by Kobayashi et al. (13), MGDF was not found to stimulate any proliferation of adult candidate stem cells when grown in single-cell/well cultures in contrast to our observation that MGDF, alone, could support the modest expansion of CFCs from a small fraction of $\mathrm{CD} 38^{-} \mathrm{CD} 34^{2+} \mathrm{Lin}^{-}$cells. Moreover, Kobayashi et al. (38) further demonstrated synergism among MGDF, SCF, and FL in supporting the growth of candidate stem cells isolated from adult bone marrow. In comparison, MGDF was relatively more potent in supporting the growth of fetal $\mathrm{CD} 38^{-} \mathrm{CD} 34^{2+} \mathrm{Lin}^{-}$cells. Notably, the synergism between MGDF and SCF in supporting the growth of CFC among these candidate stem cells was as effective as $\mathrm{SCF}+\mathrm{GM}-\mathrm{CSF}$ (30). These findings contribute to previous observations that fetal progenitors/stem cells have a lower requirement for cytokines to support their growth (27).

There is considerable interest in MGDF for its use in expanding transplantable hematopoietic cells ex vivo because of its early-acting properties as well as its potent thrombopoietic properties $(2,15)$. Neonatal or fetal grafts are likely to benefit the most from ex vivo expansion because the numbers of progenitors available from these tissues are often too small for large adult recipients. The numbers of hematopoietic progenitors that can be obtained from midgestation fetal tissues exceeds that found in umbilical cord blood, and ex vivo expansion could further increase these numbers $(33,39)$. Optimal conditions for the ex vivo expansion of progenitors need to be determined independently for fetal, neonatal, and adult tissues owing to the changes in the growth properties of hematopoietic precursors as they age. Nonetheless, optimal expansion depends on the presence of multiple growth factors that can support progenitors of different lineages as they develop from multipotent progenitors. Even though the number of fetal $\mathrm{CD} 38^{-} \mathrm{CD} 34^{2+} \mathrm{Lin}^{-}$cells supported by $\mathrm{SCF}+\mathrm{GM}-\mathrm{CSF}$ was the same as $\mathrm{SCF}+\mathrm{GM}-\mathrm{CSF}+\mathrm{MGDF}$, the latter combination supported a greater expansion of progenitors. This was likely due to MGDF's supporting the growth of $\mathrm{CD} 38^{+} \mathrm{CD} 34^{2+} \mathrm{Lin}^{-}$ cells that developed during the course of the 7-d culture period. MGDF did support CFC growth from $\mathrm{CD} 38^{+} \mathrm{CD} 34^{2+} \mathrm{Lin}^{-}$ cells, but there was no notable synergism between MGDF and the other cytokines examined. These data suggest that the progenitors found among the $\mathrm{CD} 38^{+} \mathrm{CD} 34^{2+} \mathrm{Lin}^{-}$cells that are responsive to MGDF differ from those affected by G-CSF, GM-CSF, FL, or SCF. This explanation accounts for the additive effects of these cytokines in supporting the growth of $\mathrm{CD} 38^{+} \mathrm{CD} 34^{2+} \mathrm{Lin}^{-}$cells and the greater expansion of progenitors observed with SCF+GM-CSF+MGDF.

The strong growth-promoting properties of MGDF on primitive hematopoietic progenitors from the fetus suggests that this cytokine may have use in fetal or neonatal therapy. MGDF may find use as a treatment for newborn thrombocytopenia and has been shown to be effective in increasing platelet counts in neonatal rhesus monkeys $(3,4)$. Administration of MGDF has also been shown to increase the mobilization of progenitors and stem cells (40-42). Gene therapy performed on hematopoietic stem cells isolated from fetal and/or neonatal blood is being studied as a means to treat a number of inherited disorders of the hematopoi- 
etic system (43-47). Mobilization of stem cells by MGDF administration may increase the yield of stem cells that can be harvested for therapy and returned to the fetal or neonatal circulation.

Acknowledgments We thank William Hyun and Jane W. Gordon, from the Laboratory of Cell Analysis (UCSF), and Suk Park from Ingenex for assistance with cell sorting. We thank Dr. Jae-Hung Shieh (Amgen) for providing cytokines used in this study. We also are indebted to Dr. Yuet Wai Kan for generous support.

\section{REFERENCES}

1. Kaushansky K 1995 Thrombopoietin: the primary regulator of platelet production. Blood 86:419-431

2. Kuter DJ, Begley CG 2002 Recombinant human thrombopoietin: basic biology and evaluation of clinical studies. Blood 100:3457-3469

3. Sola MC, Christensen RD, Hutson AD, Tarantal AF 2000 Pharmacokinetics, pharmacodynamics, and safety of administering pegylated recombinant megakaryocyte growth and development factor to newborn rhesus monkeys. Pediatr Res 47:208-214

4. Israels SJ 2000 Thrombopoietin and neonatal thrombocytopenia. Pediatr Res 47:176-177

5. Murray NA, Watts TL, Roberts IA 2000 Thrombopoietin in the fetus and neonate. Early Hum Dev 59:1-12

6. Kaushansky K, Lin N, Grossmann A, Humes J, Sprugel KH, Broudy VC 1996 Thrombopoietin expands erythroid, granulocyte-macrophage, and megakaryocytic progenitor cells in normal and myelosuppressed mice. Exp Hematol 24:265-269

7. Alexander WS, Roberts AW, Nicola NA, Li R, Metcalf D 1996 Deficiencies in progenitor cells of multiple hematopoietic lineages and defective megakaryocytopoiesis in mice lacking the thrombopoietin receptor c-Mpl. Blood 87:2162-2170

8. Carver-Moore K, Broxmeyer HE, Luoh S-M, Cooper S, Peng J, Burstein SA, Moore MW, de Sauvage FJ 1996 Low levels of erythroid and myeloid progenitors in thrombopoietin-and c-mpl-deficient mice. Blood 88:803-808

9. Sitnicka E, Lin N, Priestly GV, Fox N, Broudy VC, Wolf NS, Kaushansky K 1996 The effect of thrombopoietin on the proliferation and differentiation of murine hematopoietic stem cells. Blood 87:4998-5005

10. Ku H, Yonemura Y, Kaushansky K, Ogawa M 1996 Thrombopoietin, the ligand for the $\mathrm{Mpl}$ receptor, synergizes with steel factor and other early acting cytokines in supporting proliferation of primitive hematopoietic progenitors of mice. Blood $87: 4544-4551$

11. Methia N, Louache F, Vainchenker W, Wendling F 1993 Oligodeoxynucleotides antisense to the proto-oncogene c-mpl specifically inhibit in vitro megakaryocytopoiesis. Blood 82:1395-1401

12. Guerriero R, Testa U, Gabbianelli M, Mattia G, Montesoro E, Macioce G, Pace A, Ziegler B, Hassan HJ, Peschle C 1995 Unilineage megakaryocytic proliferation and differentiation of purified hematopoietic progenitors in serum-free liquid culture. Blood 86:3725-3736

13. Kobayashi M, Laver J, Kato T, Ogawa M 1996 Thrombopoietin supports proliferation of human primitive hematopoietic cells in synergy with steel factor and/or interleukin-3. Blood 88:429-436

14. Young JC, Bruno E, Luens KM, Wu S, Backer M, Murray LJ 1996 Thrombopoietin stimulates megakaryocytopoiesis, myelopoiesis, and expansion of $\mathrm{CD} 34^{+}$progenitor cells from single CD $34^{+}$Thy $-1^{+} \mathrm{Lin}^{-}$primitive progenitors. Blood 88:1619-1631

15. Heike T, Nakahata T 2002 Ex vivo expansion of hematopoietic stem cells by cytokines. Biochim Biophys Acta 1592:313-321

16. Nomura S, Ogami K, Kawamura K, Tsukamoto I, Kudo Y, Kanakura Y, Kitamura Y, Miyazaki H, Kato T 1997 Cellular localization of thrombopoietin mRNA in the live by in situ hybridization. Exp Hematol 25:565-572

17. Sola MC, Juul SE, Meng YG, Garg S, Sims P, Calhoun DA, Dame JB, Christensen D 1999 Thrombopoietin (Tpo) in the fetus and neonate: Tpo concentrations in preterm and term neonates, and organ distribution of Tpo and its receptor (c-mpl) during human fetal development. Early Hum Dev 53:239-250

18. Wolber EM, Dame C, Fahnenstich H, Hofmann D, Bartmann P, Jelkmann W, Fandrey J 1999 Expression of the thrombopoietin gene in human fetal and neonatal tissues. Blood 94:97-105

19. Porcelijn L, Folman CC, de Haas M, Kanhai HH, Murphy MF, von dem Borne AE, Bussel JB 2002 Fetal and neonatal thrombopoietin levels in alloimmune thrombocytopenia. Pediatr Res 52:105-108

20. Sainio S, Javela K, Kekomaki R, Teramo K 2000 Thrombopoietin levels in cord blood plasma and amniotic fluid in fetuses with alloimmune thrombocytopenia and healthy controls. Br J Haematol 109:330-335

21. Murray LJ, Mandich D, Bruno E, DiGiusto RK, Fu WC, Sutherland DR, Hoffman R, Tsukamoto A 1996 Fetal bone marrow CD34+CD41+ cells are enriched for multipotent hematopoietic progenitors, but not for pluripotent stem cells. Exp Hematol 24:236-245

22. Bárcena A, Muench MO, Song KS, Ohkubo T, Harrison MR 1999 Role of CD95/Fas and its ligand in the regulation of the growth of human $\mathrm{CD} 34^{++} \mathrm{CD} 38^{-}$fetal liver cells. Exp Hematol 27:1428-1439
23. Muench MO, Shieh J-H 1999 In vitro development of megakaryocytes and platelets. In: Koller MR, Palsson BO, Masters JRW (eds) Human Cell Culture. Kluwer Academic Publishers, Dordrecht, pp 287-315

24. Ma DC, Sun YH, Zuo W, Chang KZ, Chu JJ, Liu YG 2000 CD34+ cells derived from fetal liver contained a high proportion of immature megakaryocytic progenitor cells. Eur J Haematol 64:304-314

25. Zeigler FC, de Sauvage F, Widmer HR, Keller GA, Donahue C, Schreiber RD, Malloy B, Hass P, Eaton D, Matthews W 1994 In vitro megakaryocytopoietic and thrombopoietic activity of c-mpl ligand (TPO) on purified murine hematopoietic stem cells. Blood 84:4045-4052

26. Lansdorp PM, Dragowska W, Mayani H 1993 Ontogeny-related changes in proliferative potential of human hematopoietic cells. J Exp Med 178:787-791

27. Weekx SF, Van Bockstaele DR, Plum J, Moulijn A, Rodrigus I, Lardon F, De Smedt M, Nijs G, Lenjou M, Loquet P, Berneman ZN, Snoeck HW 1998 CD34++ CD38and $\mathrm{CD} 34+\mathrm{CD} 38+$ human hematopoietic progenitors from fetal liver, cord blood, and adult bone marrow respond differently to hematopoietic cytokines depending on the ontogenic source. Exp Hematol 26:1034-1042

28. Weekx SF, Plum J, Van Cauwelaert P, Lenjou M, Nijs G, De Smedt M, Vanhove M, Muylaert P, Van Bockstaele DR, Berneman ZN, Snoeck HW 1999 Developmentally regulated responsiveness to transforming growth factor-beta is correlated with functional differences between human adult and fetal primitive hematopoietic progenitor cells. Leukemia 13:1266-1272

29. Muench MO, Cupp J, Polakoff J, Roncarolo MG 1994 Expression of CD33, CD38 and HLA-DR on CD34+ human fetal liver progenitors with a high proliferative potential. Blood 83:3170-3181

30. Muench MO, Roncarolo MG, Menon S, Xu Y, Kastelein R, Zurawski S, Hannum CH, Culpepper J, Lee F, Namikawa R 1995 FLK-2/FLT-3 ligand (FL) regulates the growth of early myeloid progenitors isolated from human fetal liver. Blood 85:963-972

31. Muench MO, Roncarolo M-G, Rosnet O, Birnbaum D, Namikawa R 1997 Colonyforming cells expressing high levels of CD34 are the main targets for granulocyte colony-stimulating factor and macrophage colony-stimulating factor in the human fetal liver. Exp Hematol 25:277-287

32. Muench MO, Suskind DL, Bárcena A 2002 Isolation, growth and identification of colony-forming cells with erythroid, myeloid, dendritic cell and NK-cell potential from human fetal liver. Biol Proced Online 4:10-23

33. Golfier F, Bárcena A, Cruz J, Harrison MR, Muench MO 1999 Mid-trimester fetal livers are a rich source of $\mathrm{CD} 34^{+/++}$cells for transplantation. Bone Marrow Transplant 24:451-461

34. Bradley TR, Hodgson GS 1979 Detection of primitive macrophage progenitor cells in mouse bone marrow. Blood 54:1446-1450

35. Muench MO, Namikawa R 2001 Disparate regulation of human fetal erythropoiesis by the microenvironments of the liver and bone marrow. Blood Cells Mol Dis 27:377-390

36. Shah AJ, Smogorzewska EM, Hannum C, Crooks GM 1996 Flt3 ligand induces proliferation of quiescent human bone marrow $\mathrm{CD} 34^{+} \mathrm{CD} 38^{-}$cells and maintains progenitor cells in vitro. Blood 87:3563-3570

37. Rebel VI, Miller CL, Thornbury GR, Dragowska WH, Eaves CJ, Lansdorp PM 1996 A comparison of long-term repopulating hematopoietic stem cells in fetal liver and adult bone marrow from the mouse. Exp Hematol 24:638-648

38. Kobayashi M, Laver JH, Lyman SD, Kato T, Miyazaki H, Ogawa M 1997 Thrombopoietin, steel factor and the ligand for flt $3 / \mathrm{flk} 2$ interact to stimulate the proliferation of human hematopoietic progenitors in culture. Int J Hematol 66:423-434

39. Golfier F, Bárcena A, Harrison MR, Muench MO 2000 Fetal bone marrow as a source of stem cells for in utero or postnatal transplantation. Br J Haematol 109:173-181

40. Torii Y, Nitta Y, Akahori H, Tawara T, Kuwaki T, Ogami K, Kato T, Miyazaki H 1998 Mobilization of primitive haemopoietic progenitor cells and stem cells with long-term repopulating ability into peripheral blood in mice by pegylated recombinant human megakaryocyte growth and development factor. Br J Haematol 103:1172-1180

41. Honda K, Takenaka K, Shinagawa K, Ishimaru F, Ikeda K, Niiya K, Harada M 2001 Synergistic effects of pegylated recombinant human megakaryocyte growth and development factor and granulocyte colony-stimulating factor on mobilization of hematopoietic progenitor and stem cells with long-term repopulating ability into peripheral blood in mice. Bone Marrow Transplant 28:329-334

42. Somlo G, Sniecinski I, ter Veer A, Longmate J, Knutson G, Vuk-Pavlovic S, Bhatia R, Chow W, Leong L, Morgan R, Margolin K, Raschko J, Shibata S, Tetef M, Yen Y, Forman S, Jones D, Ashby M, Fyfe G, Hellmann S, Doroshow JH 1999 Recombinant human thrombopoietin in combination with granulocyte colonystimulating factor enhances mobilization of peripheral blood progenitor cells, increases peripheral blood platelet concentration, and accelerates hematopoietic recovery following high-dose chemotherapy. Blood 93:2798-2806

43. Migliaccio G, Baiocchi M, Hamel N, Eddleman K, Migliaccio AR 1996 Circulating progenitor cells in human ontogenesis: response to growth factors and replating potential. J Hematother 5:161-170

44. Shields LE, Kiem HP, Andrews RG 2000 Highly efficient gene transfer into preterm CD34 hematopoietic progenitor cells. Am J Obstet Gynecol 183:732-737

45. Ohkubo T, Bárcena A, Smith CA, Harrison MR, Muench MO 2001 High-efficiency retroviral transduction of fetal liver CD38-CD34++ cells: implications for in utero and ex utero gene therapy. Fetal Diagn Ther 16:299-307

46. Murdoch B, Gallacher L, Awaraji C, Hess DA, Keeney M, Jay K, Chadwick K, Fowley SR, Howson-Jan K, Chin Yee I, Wu D, Srour ED, Fellows F, Bhatia M 2001 Circulating hematopoietic stem cells serve as novel targets for in utero gene therapy. FASEB J 15:1628-1630

47. Surbek DV, Young A, Danzer E, Schoeberlein A, Dudler L, Holzgreve W 2002 Ultrasound-guided stem cell sampling from the early ovine fetus for prenatal ex vivo gene therapy. Am J Obstet Gynecol 187:960-963 